\title{
MODELING, SIMULATION, AND VALIDATION OF AN ELECTRIC HEATER MODEL OPERATING IN THE TRANSIENT REGIME
}

\author{
Rafael Oliveira Defendi ${ }^{1}$ \\ Paulo Roberto Paraíso ${ }^{2}$ \\ Luiz Mario de Matos Jorge 3 $^{3}$
}

\begin{abstract}
Resumo - Neste trabalho foi desenvolvido um modelo dinâmico de um aquecedor elétrico de ar operando em regime transiente, partindo de um balanço de energia no aquecedor considerando a energia fornecida para o sistema pelas resistências elétricas, a energia perdida para as vizinhanças por convecção e o acúmulo de energia no sistema, resultando num modelo dinâmico representado por uma equação diferencial ordinária de primeira ordem com dois parâmetros a serem determinados. Os parâmetros do modelo foram ajustados pelo método dos mínimos quadrados. Na validação do modelo foram utilizadas medidas experimentais de temperatura do ar na saída do aquecedor, obtidas a partir de diversas perturbações na voltagem imposta ao aquecedor elétrico aguardando que o sistema alcançasse a condição de regime permanente. Os resultados obtidos revelaram que o modelo representa adequadamente o comportamento do sistema operando tanto em regime transiente como permanente e apontam que este modelo pode ser utilizado para fins de simulação, análise e projeto de aquecedores elétricos.
\end{abstract}

Palavras-chave: Modelo Dinâmico; Aquecedor Elétrico; Coeficiente Global de Transferência de Calor.

Abstract - A dynamic model for an electric air heater operating in the transient regime was developed from an energy balance in the heater, taking into account the energy supplied to the system by the electric resistances, the energy lost to the surroundings by convection, and the accumulation of energy in the system. The resulting model was represented by an ordinary differential equation of the first order with two parameters to be determined. The model parameters were adjusted by the least squares method. The experimental temperature measurements used to validate the model were obtained at the heater outlet after different disturbances in the electric heater temperature through changes in the voltage applied to the heater and waiting for the system to reach steady state condition. The results revealed that the model adequately represented the behavior of the system in both transient and permanent regimes and showed that this model can be used for the simulation, analysis, and design of electric heaters.

Keywords: Dynamic model; Electric heater; Overall heat transfer coefficient.

\footnotetext{
${ }^{1}$ Chemical Engineering Department, State University of Maringá (UEM), rafael.defendi@ yahoo.com.br

${ }^{2}$ Chemical Engineering Department, State University of Maringá (UEM), paulo@ deq.uem.br

${ }^{3}$ Chemical Engineering Department, State University of Maringá (UEM), lmmj@ deq.uem.br
} 


\section{INTRODUCTION}

Electric heaters are devices capable of converting electrical energy into heat. These heaters can be used to heat fluids such as water and air for industrial processes such as the drying of solids and processes that require heat exchangers. According to Mathur (2011), these equipments are usually used when the heat demand is low or for plant startups prior to the availability of hot oil or stream. Electric heaters can also be used to supply deficient heat capacity on the surface of outdoor heat exchanger where frosting condition may occur due to low-temperature and high-humidity during winter (Kwak and Bai, 2010). It is possible to increase the heating capacity and the coefficient of performance (COP) when using electric heaters in this system (Kwak and Bai, 2010). In the cold storage process, electric heaters are used to defrost the frost deposition on the evaporator that may occur due to low temperature, which can decrease the cooling capacity and the COP (Yin et al., 2012).

Temperature control in these processes is extremely important, especially for the drying of grains, as reported by Coutinho et al. (2004). According to these authors, the lack of temperature control in the drying of seeds can suppress the germination. Furthermore, according to Silva (2000), the amount of heat supplied in a drying process has definite effect on the nutritional value of the grain.

Fluid heating systems are directly related to the energy cost of the process. According to Luz et al. (2006), drying is a step of agricultural production that consumes a lot of energy. Reinato et al. (2002) argue that the efficient management of the drying step contributes to reduced operational costs due to the economy of energy that is provided by the optimal control of the process. Therefore, modeling, simulating and validating the performance of heating systems is extremely important for process optimization.
These models can also assist the air temperature control where temperature modulation is necessary such as the intermittent drying. Recently, the intermittent operation mode of the drying process of crops products has been investigated by a significant number of authors (Chua et al., 2000a,b; Chua et al., 2003; Holowaty et al., 2012; Kowalski e Pawlowski, 2011; Meneghetti et al., 2012; Oliveira \& Rocha, 2007; Putranto et al., 2011; Ramallo et al., 2010). One of the main aims of the intermittent operation is to minimize the energy consumption and to achieve better quality of products (Putranto et al., 2011). Contrary to the traditional operation mode, the intermittent drying supply the system with time-varying heat input focusing to obtain the best operating conditions. According to Chua et al. (2003), this new method is beneficial for products whose drying process is controlled by internal diffusion of heat and moisture content, namely for drying in the falling rate period. These authors also add that this time-varying heat mode is also beneficial for heatsensitive materials such as foods, herbs, spices, herbal medicines, pharmaceutical and neutraceutical substances. In this context, it is important to adjust models that can describe this time-varying heat input (transient regime).

Temperature control of electric heaters is done by controlling the voltage applied to the resistance of the fluid heating system. For a given voltage, the fluid will be heated to a certain temperature according to the conditions of the environment in which the heater is inserted. Furthermore, once a disturbance is applied by varying the voltage to a specific value, the system takes a certain time to reach steady state condition, when the temperature stabilizes.

Based on the discussion above, the objective of the present study was to propose a dynamic model of an electric heater operating in the transient regime that could correlate the air temperature profile at the heater outlet with the applied voltage and with the conditions of the environment in which the heater 
was inserted. The model was validated against experimental data obtained in an electric air heating system used in a fixed bed dryer at bench scale. In addition, the model was applied in the simulation of system with temperature modulation.

\section{MATERIALS AND METHODS}

\subsection{Materials}

Air was supplied to the system by a 7 bar air compressor. A rotameter was installed in the pipeline to measure air flow rate. The air went through an electric heater with resistance of $7.60 \Omega$ and surface area of $1.07 .10^{3} \mathrm{~cm}^{2}$, which was attached to a variable voltage regulator (VARIAC), and then passed through the fixed bed dryer with internal diameter of $6 \mathrm{~cm}$ and length of $30 \mathrm{~cm}$, without packing. A digital psychrometer and a digital stopwatch were also used.

\subsection{Experimental procedure}

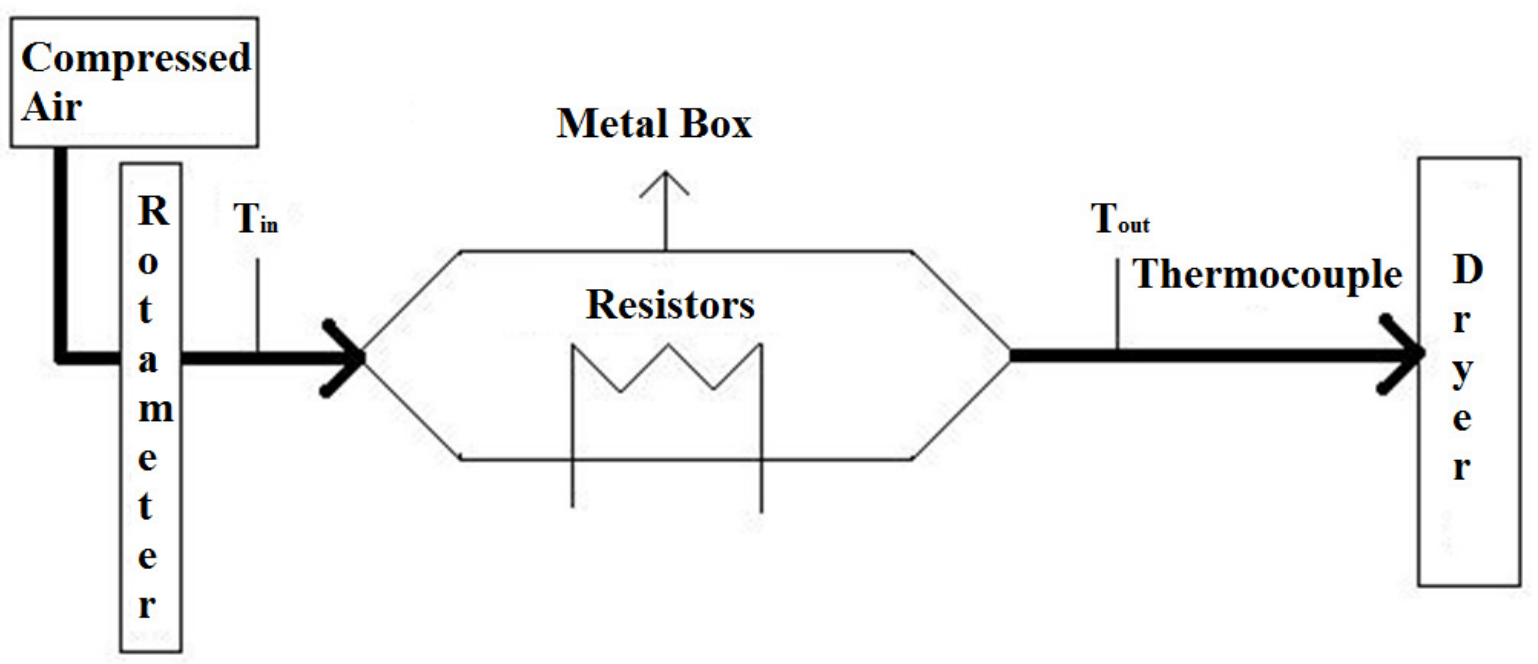

Figure 1 - Electric Heater

\subsection{Dynamic model}

To obtain a mathematical model
he air heating system, an energy
ce was applied to the heater box and
be represented by the following
ion:

To obtain a mathematical model
for the air heating system, an energy
balance was applied to the heater box and
it can be represented by the following
equation:

To obtain a mathematical model
for the air heating system, an energy
balance was applied to the heater box and
it can be represented by the following
equation:

To obtain a mathematical model
for the air heating system, an energy
balance was applied to the heater box and
it can be represented by the following
equation: equation:
The experimental procedure consisted of the following steps:

1) Air flow rate was set at 100 $\mathrm{L} / \mathrm{min}$;

2) Ambient and inlet air temperature were measured with the psychrometer;

3) The voltage applied to the air heater resistance was adjusted so as to raise the air temperature at the heater outlet $\left(T_{\text {out }}\right)$ to $53{ }^{\circ} \mathrm{C}$;

4) As soon as $\mathrm{T}_{\text {out }}$ reached $53^{\circ} \mathrm{C}$, the stopwatch was started and the variable voltage regulator was simultaneously set at $6.0 \%$, which is equivalent to $6.6 \mathrm{~V}$;

5) $T_{\text {out }}$ was then measured until it reached a constant value (steady state), using the thermocouple located just after the heater, as depicted in Figure 1;

6) Steps 1 through 5 were repeated for each condition of initial $T_{\text {out }}$, voltage, and air flow rate, according to Table 1.

For temperature modulation experiment, step perturbations were imposed to the voltage applied to the heater every $5 \mathrm{~min}$ during $30 \mathrm{~min}$ of heating, setting the value between 10 and $26 \%$, alternately and consecutively.

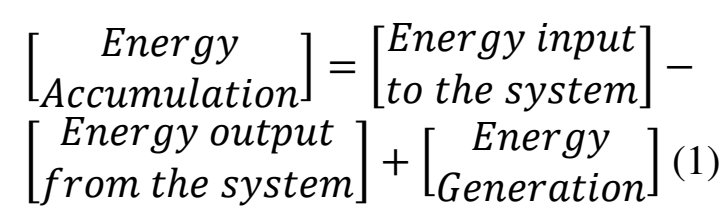

The following assumptions were made for this system: 
Table 1 - Experimental conditions

\begin{tabular}{ccc|ccc}
\hline \multicolumn{3}{c|}{ Air flow rate of $100 \mathrm{~L} / \mathrm{min}$} & \multicolumn{3}{c}{ Air flow rate of $200 \mathrm{~L} / \mathrm{min}$} \\
\hline Experiment & Voltage $(\%)$ & Initial $\mathrm{T}_{\text {out }}\left({ }^{\circ} \mathrm{C}\right)$ & Experiment & Voltage $(\%)$ & Initial $\mathrm{T}_{\text {out }}\left({ }^{\circ} \mathrm{C}\right)$ \\
\hline 1 & 6 & 53 & 14 & 9 & 63 \\
2 & 6 & 44 & 15 & 10 & 25 \\
3 & 7 & 42 & 16 & 10 & 56 \\
4 & 9 & 56 & 17 & 13 & 65 \\
5 & 9 & 62 & 18 & 15 & 25 \\
6 & 17 & 60 & 19 & 18 & 55 \\
7 & 20 & 22 & 20 & 29 & 32 \\
8 & 22 & 42 & 21 & 29 & 30 \\
9 & 22 & 62 & 22 & 30 & 63 \\
10 & 25 & 25 & 23 & 35 & 29 \\
11 & 25 & 49 & 24 & 35 & 52 \\
12 & 25 & 40 & 25 & 35 & 32 \\
13 & 26 & 52 & & & \\
\hline
\end{tabular}

- Physical properties such as specific heat, thermal conductivity, and heater resistance are constant over time;

- The thermal conductivity of the material is such that it provides a constant temperature profile around the box;

- The outlet air temperature is equal to the box temperature;

With these considerations, each term of the energy balance results in:

$$
\begin{gathered}
{\left[\begin{array}{c}
\text { Energy input } \\
\text { to the system }
\end{array}\right]=} \\
\dot{m}_{\text {air }} \cdot c p_{\text {air. }}\left(T_{\text {in }}-T_{\text {out }}\right)= \\
-\dot{m}_{\text {air }} \cdot c p_{\text {air }} \cdot\left(T_{\text {out }}-T_{\text {in }}\right) \\
{\left[\begin{array}{c}
\text { Energy output } \\
\text { from the system }
\end{array}\right]=} \\
\text { h. As. }\left(T_{\text {out }}-T_{\text {amb }}\right) \\
{\left[\begin{array}{c}
\text { Energy } \\
\text { Generation }
\end{array}\right]=\frac{V^{2}}{R}} \\
{\left[\begin{array}{c}
\text { Energy } \\
\text { Accumulation }
\end{array}\right]=} \\
m_{\text {box }} \cdot c p_{\text {box }} \cdot \frac{d T_{\text {box }}}{d t}= \\
m_{\text {box }} \cdot c p_{\text {box }} \cdot \frac{d T_{\text {out }}}{d t}
\end{gathered}
$$

where $\dot{m}_{\text {air }}$ is the air mass flow rate, $c p_{\text {air }}$ is the air specific heat, $T_{i n}$ is the air temperature at the heater entrance, $T_{\text {out }}$ is the air temperature at the heater exit, $h$ is the overall heat transfer coefficient, $A s$ is the box superficial area, $V$ is the voltage applied to the resistors, $R$ is the resistance, $t$ is the time, $m_{b o x}$ is the mass of the box, $c p_{b o x}$ is the box specific heat and $T_{b o x}$ is the box temperature.

The energy input to the system was calculated by the sensible heat due to variation in the inlet and outlet air temperature, while the energy output was represented by the heat lost by natural convection to the surroundings. The average temperature of the air leaving the heater approached the heater temperature, and it was used in Newton's law of cooling. As for energy generation, it came from the heat supplied by the heater resistance. Finally, energy accumulation in the system was represented by the variation of the heater energy with time.

Replacing each term in the global energy balance the following equation was obtained:

$$
\begin{gathered}
m_{\text {box }} \cdot c p_{\text {box }} \cdot \frac{d T_{\text {out }}}{d t}= \\
-\dot{m}_{\text {air }} \cdot c p_{a i r} \cdot\left(T_{o u t}-T_{\text {in }}\right)- \\
\text { h.As. }\left(T_{\text {out }}-T_{a m b}\right)+\frac{V^{2}}{R}
\end{gathered}
$$

Equation (6) represents the first order differential equation that resulted from the dynamic model. It can be rewritten in the form of Equation (7):

$$
\begin{gathered}
A . \frac{d T_{\text {out }}}{d t}=-B .\left(T_{\text {out }}-T_{\text {in }}\right)- \\
C .\left(T_{\text {out }}-T_{\text {amb }}\right)+\frac{V^{2}}{R}
\end{gathered}
$$


where $A, B$, and $C$ are the model parameters that can be determined by:

$$
\begin{gathered}
A=m_{b o x} . c p_{b o x} \\
B=\dot{m}_{\text {air }} . c p_{\text {air }} \\
C=h . A s
\end{gathered}
$$

The values of density and specific heat of air could be obtained from the literature (Perry and Green, 1998) to estimate the value of parameter $B$, which resulted in 2.02 and $4.04 \mathrm{~J} / \mathrm{sK}$ for the flow rates of 100 and $200 \mathrm{~L} / \mathrm{min}$, respectively.

Equation 6 represents the model for electrical heaters operating in transient regime and it can be simplified for permanent regime when there is no variance of energy with time leading to the model as proposed by Coutinho et al. (2004):

$$
\begin{gathered}
\frac{V^{2}}{R}=B \cdot\left(T_{\text {out }}-T_{\text {in }}\right)+ \\
\text { C. }\left(T_{\text {out }}-T_{\text {amb }}\right)
\end{gathered}
$$

The analytical solution of the transient model (Equation 7) results in:

$$
T_{\text {out }}=e^{\frac{t}{D}}\left(E+T_{\text {out }}\right)-E
$$

where $T_{o u t_{0}}$ is the initial value for the air temperature at the heater outlet and the variables $D$ and $E$ are calculated respectively with Equations 13 and 14.

$$
\begin{gathered}
D=-\frac{A}{B+C} \\
E=-\frac{\frac{V^{2}}{R}+B \cdot T e+C \cdot T a m b}{B+C}
\end{gathered}
$$

Parameters $A$ and $C$ were adjusted based on experimental data of applied voltage, air temperature at the heater inlet, ambient temperature, and air temperature at the heater outlet. These parameters were fitted by minimizing the following objective function (residual sum of squares):

$$
\phi=\sum\left(T_{\exp }-T_{p r e}\right)^{2}
$$

where $T_{\text {exp }}$ is the experimental temperature at the heater outlet and $T_{p r e}$ is the value of this temperature predicted by the model. The reduced chi-square $\left(\chi^{2}\right)$, the root mean square error (RMSE) and the increased modeling efficiency $(E F)$ were used to evaluate the efficiency of the adjustment. According to Meisami-asl et al. (2010), the reduced chi-square determines the goodness of the fit and represents the mean square of the deviation between experimental and predicted data. Then, an ideal value for $\chi^{2}$ is the minimum value possible to be obtained. These authors also add that the RMSE value is the deviation between experimental and predicted data and $E F$ is related to the ability of the model to predict the system behavior. Ideally, it is interesting to achieve zero for the RMSE value and 1.0 for the $E F$ value. These statistical parameters were calculated with the following equations:

$$
\chi^{2}=\frac{\sum\left(T_{\text {exp }}-T_{\text {pre }}\right)^{2}}{N o-N c}
$$

$R M S E=\left(\frac{1}{N o} \sum\left(T_{\text {pre }}-T_{\text {exp }}\right)^{2}\right)^{\frac{1}{2}}$

$E F=\frac{\sum\left(T_{\text {exp }}-\bar{T}_{\text {exp }}\right)^{2}-\sum\left(T_{p r e}-T_{e x p}\right)^{2}}{\sum\left(T_{\text {exp }}-\bar{T}_{\text {exp }}\right)^{2}}$

where $N o$ is the number of observations, $N c$ is the number of constants of the model and $\bar{T}_{\text {exp }}$ is the mean value of the experimental data.

The overall heat transfer coefficient $(h)$ was estimated from parameter $C$ and compared with literature values. According to Perry and Green (1998), the value of $h$ in heat exchangers with air (cold stream) and steam (hot stream) is between 6 and $17 \mathrm{~W} / \mathrm{m}^{2} \mathrm{~K}$ for natural convection and between 23 and $45 \mathrm{~W} / \mathrm{m}^{2} \mathrm{~K}$ for forced convection. According to Bird et al. (2002), $h$ values for heat exchange between gases are in the range $3-20 \mathrm{~W} / \mathrm{m}^{2} \mathrm{~K}$ for free convection and $10-100 \mathrm{~W} / \mathrm{m}^{2} \mathrm{~K}$ for forced convection. In the case of heat exchange between gases, where one of them is 
flowing (forced convection) and the other is stationary (natural convection), $h$ is between 3 and $10 \mathrm{~W} / \mathrm{m}^{2} \mathrm{~K}$. According to the correlation proposed by Churchill and Chu (1975) for horizontal cylinders of 10 $\mathrm{cm}$ in diameter with a difference of 1$40{ }^{\circ} \mathrm{C}$ between the heated gas and ambient air temperatures, the value of $h$ is between 2 and $7.5 \mathrm{~W} / \mathrm{m}^{2} \mathrm{~K}$.

Finally, the model was simulated with the adjusted parameters and the deviations between the experimental temperature at the heater outlet and the temperature estimated by the model were calculated.

\section{RESULTS AND DISCUSSION}

The adjusted value of parameter $\mathrm{C}$ was $1.105 \mathrm{~J} / \mathrm{sK}$, resulting in a value of $10.3 \mathrm{~W} / \mathrm{m}^{2} \mathrm{~K}$ for the overall heat transfer coefficient, which was in the expected range according to the literature. The average value for parameter A was 697.7
$J / K$. Table 2 shows the values of the objective function minimized and statistical parameters.

From these results, it is possible to observe that experiments 2 and 18 had the best adjustment due to their great statistical parameters. On the other hand, the worst value obtained were from experiments 23 and 25 . However, it was verified that the difference between theses statistical values is due to the number of observations of experiments 23 and 25 that are higher in comparison with experiments 2 and 18 . The great number of observations increased the values of the parameters $\phi, \chi^{2}$ and RMSE. The great adjustment of all of these experiments is observed on the behavior of curves from Figures 2, 3, 4 and 5 which presents the heating curves respectively for experiments $2,18,23$ and 25.

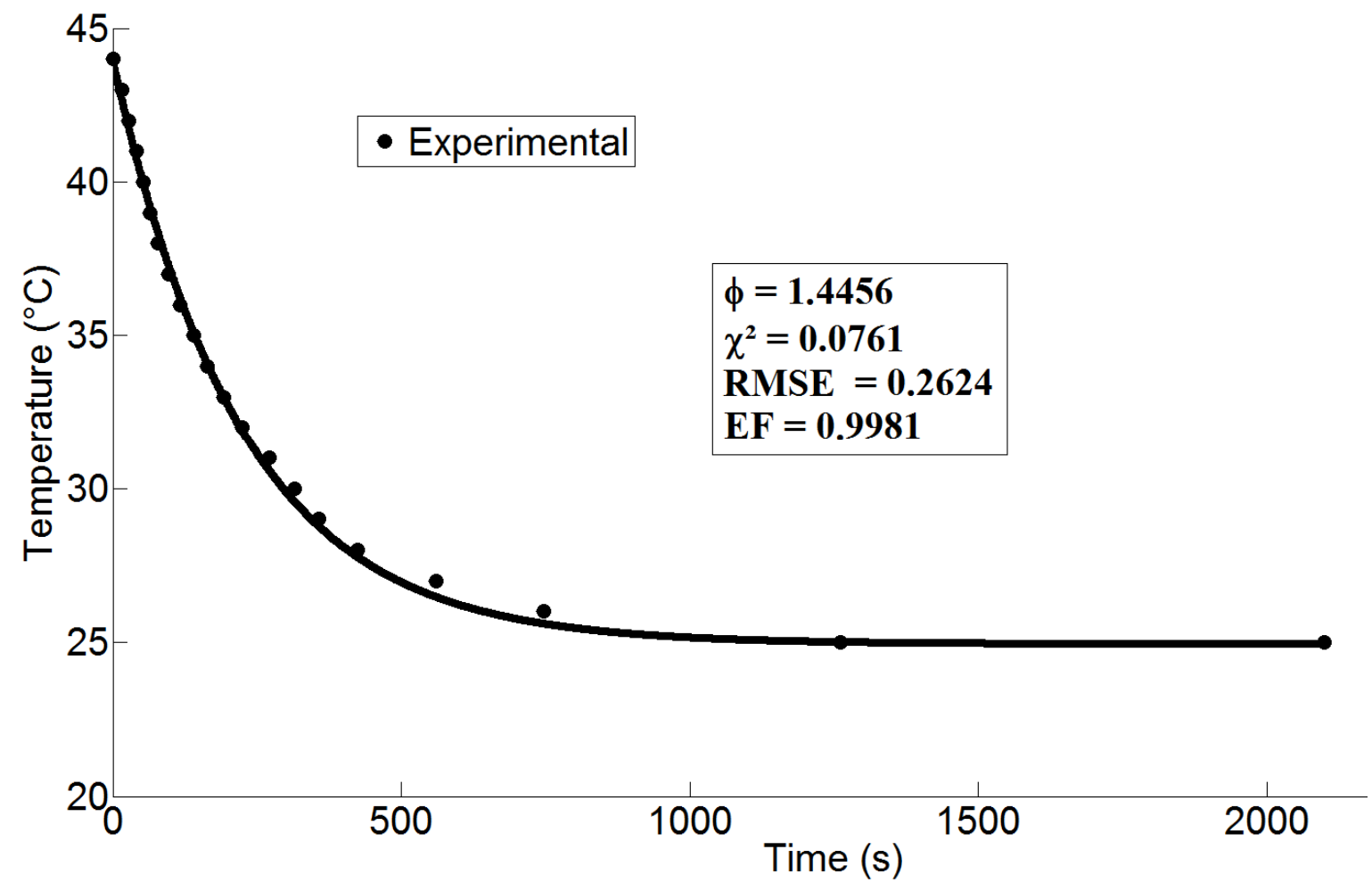

Figure 2 - Temperature Profile for Experiment 2 
Table 2 - Objective function minimized and statistical parameters

\begin{tabular}{|c|c|c|c|c|}
\hline Experiment & $\phi$ & $\chi^{2}$ & RMSE & $\mathrm{EF}$ \\
\hline 1 & 23.9934 & 0.8569 & 0.8943 & 0.9892 \\
\hline 2 & 1.4456 & 0.0761 & 0.2624 & 0.9981 \\
\hline 3 & 1.5398 & 0.1283 & 0.3316 & 0.9929 \\
\hline 4 & 6.9757 & 0.2405 & 0.4744 & 0.9972 \\
\hline 5 & 27.6638 & 0.9221 & 0.9298 & 0.9897 \\
\hline 6 & 3.4729 & 0.1929 & 0.4167 & 0.9946 \\
\hline 7 & 8.0042 & 0.3638 & 0.5775 & 0.9929 \\
\hline 8 & 2.5081 & 0.2787 & 0.4775 & 0.9751 \\
\hline 9 & 1.0651 & 0.1183 & 0.3112 & 0.9894 \\
\hline 10 & 7.4785 & 0.2412 & 0.4760 & 0.9975 \\
\hline 11 & 6.8018 & 0.5232 & 0.6734 & 0.9722 \\
\hline 12 & 3.4986 & 0.1749 & 0.3988 & 0.9960 \\
\hline 13 & 2.9613 & 0.2692 & 0.4773 & 0.9806 \\
\hline 14 & 31.9040 & 0.9384 & 0.9414 & 0.9917 \\
\hline 15 & 1.2568 & 0.2514 & 0.4237 & 0.9450 \\
\hline 16 & 19.2041 & 0.7682 & 0.8434 & 0.9881 \\
\hline 17 & 27.1688 & 0.8233 & 0.8811 & 0.9923 \\
\hline 18 & 0.7019 & 0.0780 & 0.2526 & 0.9919 \\
\hline 19 & 12.9579 & 0.6820 & 0.7855 & 0.9827 \\
\hline 20 & 20.8213 & 0.9915 & 0.9515 & 0.9790 \\
\hline 21 & 15.1500 & 0.6312 & 0.7633 & 0.9895 \\
\hline 22 & 1.4547 & 0.1818 & 0.3814 & 0.9804 \\
\hline 23 & 67.9101 & 1.9403 & 1.3548 & 0.9838 \\
\hline 24 & 5.8490 & 0.4874 & 0.6464 & 0.9728 \\
\hline 25 & 37.9027 & 1.1486 & 1.0406 & 0.9893 \\
\hline Average & 13.5876 & 0.5323 & 0.6387 & 0.9861 \\
\hline
\end{tabular}

Moreover, it was verified that the electric heater model could estimate the air temperature outlet during the heating process of all experiments with a maximum deviation near to $3,0 \%$ as it is illustrated in Figure 6. Evaluating the temperature range studied during experiments, this deviation is lower than the thermocouple precision $\left( \pm 2,2{ }^{\circ} \mathrm{C}\right)$ informed by the producer.

The electric heat model could also describe the periodic temperature behavior from experiment with temperature modulation. Figure 7 depicts the outlet air temperature for the experiment with applied voltage varying alternately and continuously between the points of 6 and $26 \%$. It was possible to describe this time-varying heating process with a global deviation near to $3 \%$ as it is shown in Figure 8. This deviation is also lower than the thermocouple precision under the temperature range achieved. 


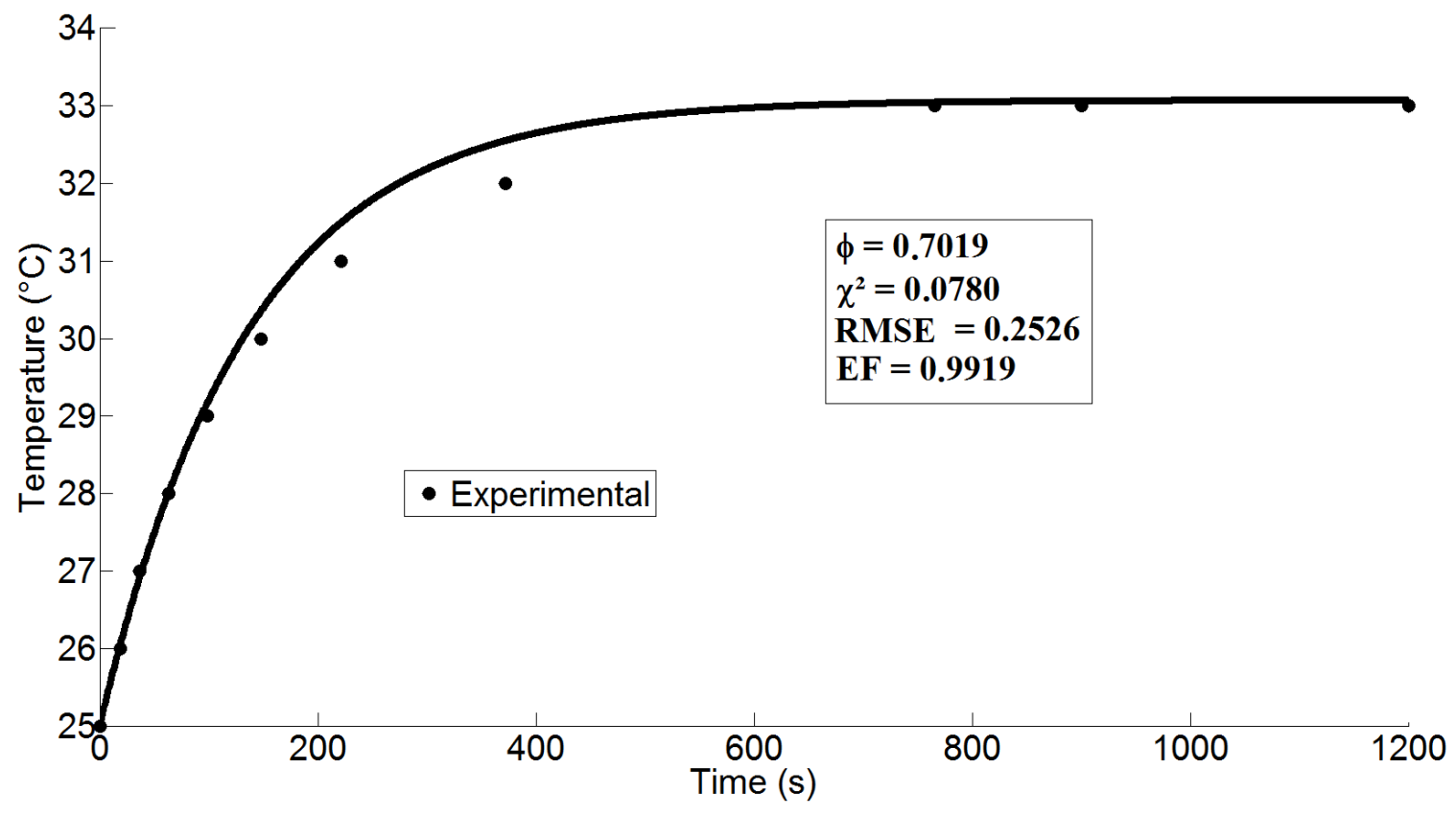

Figure 3 - Temperature Profile for Experiment 18

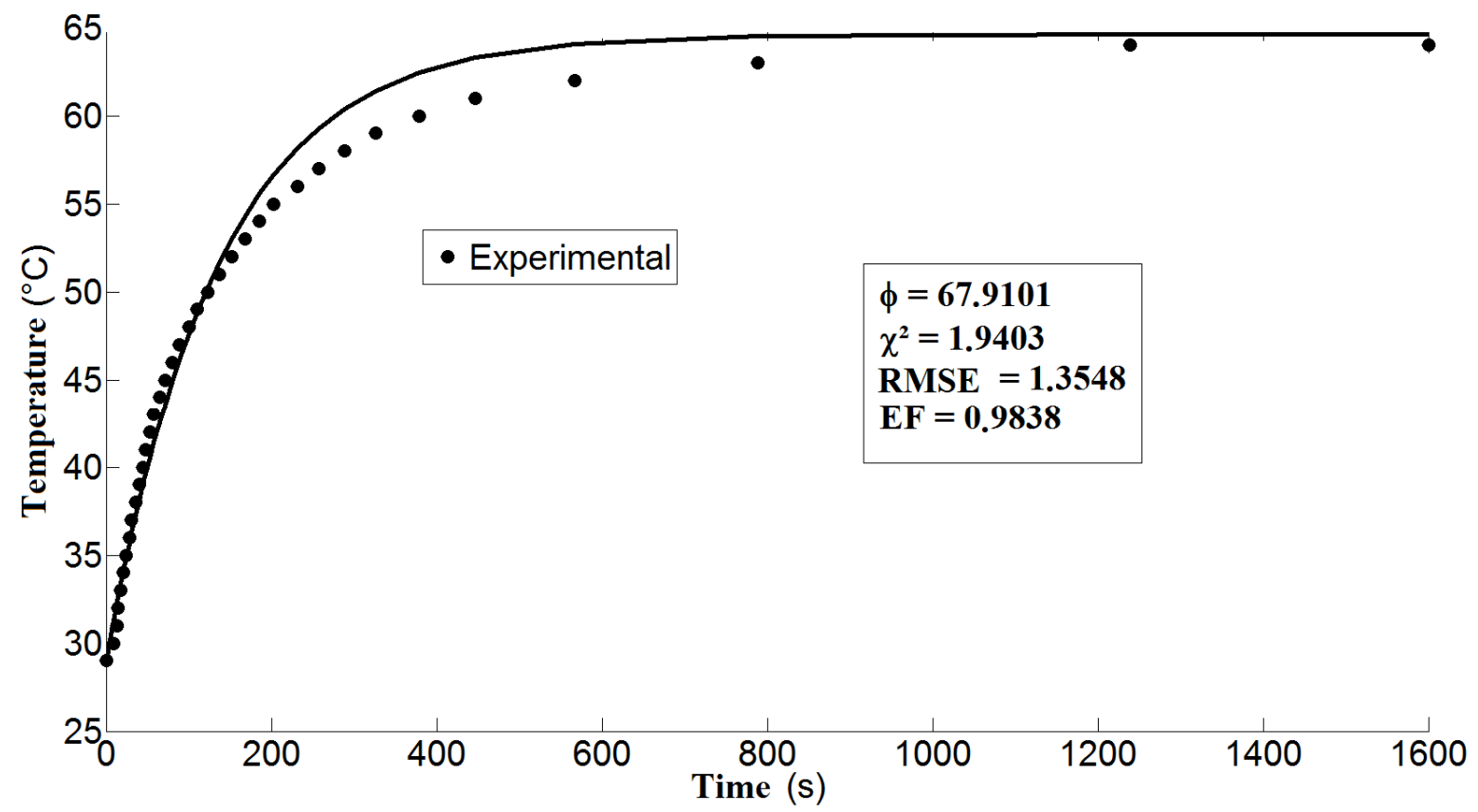

Figure 4 - Temperature Profile for Experiment 23 


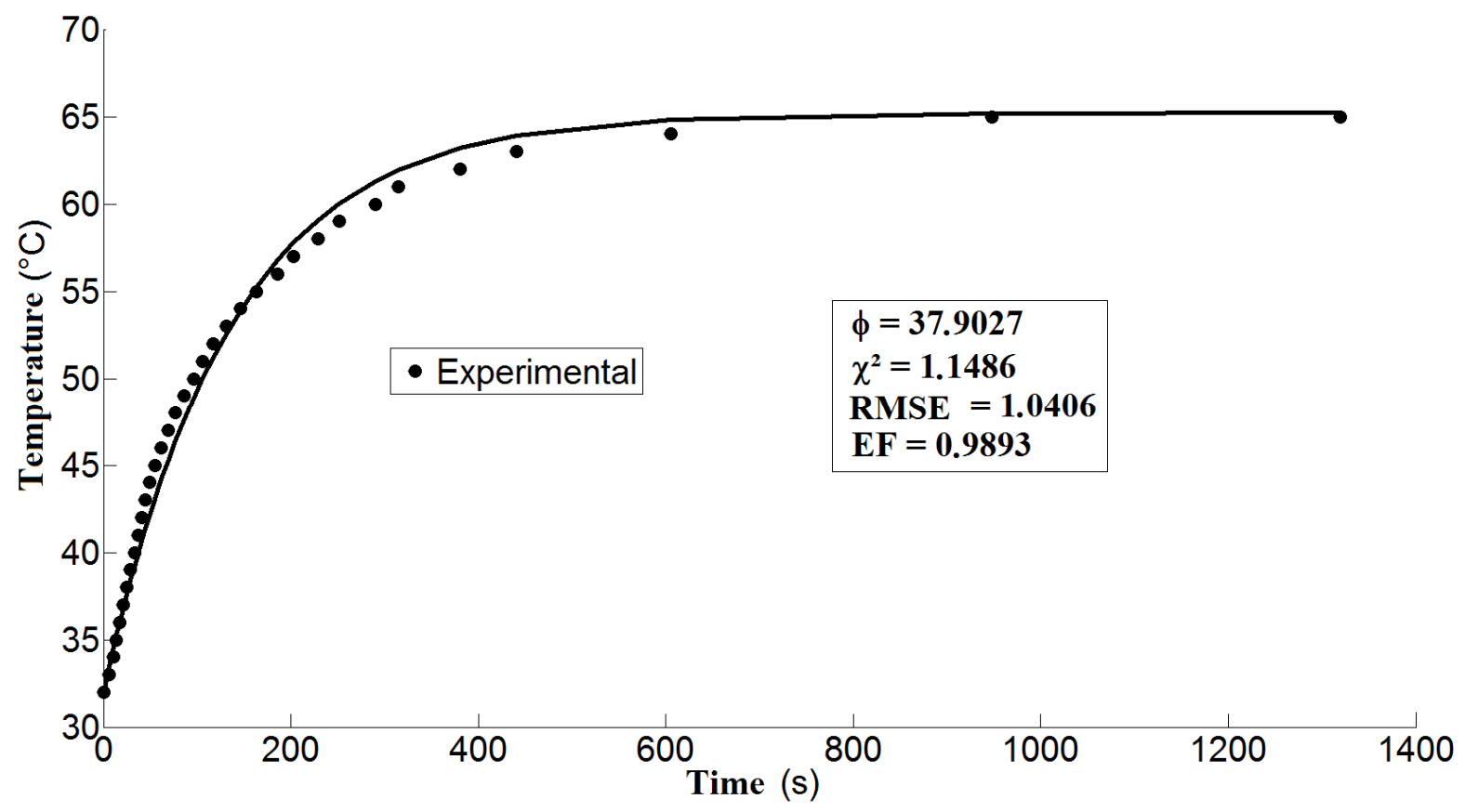

Figure 5 - Temperature Profile for Experiment 25

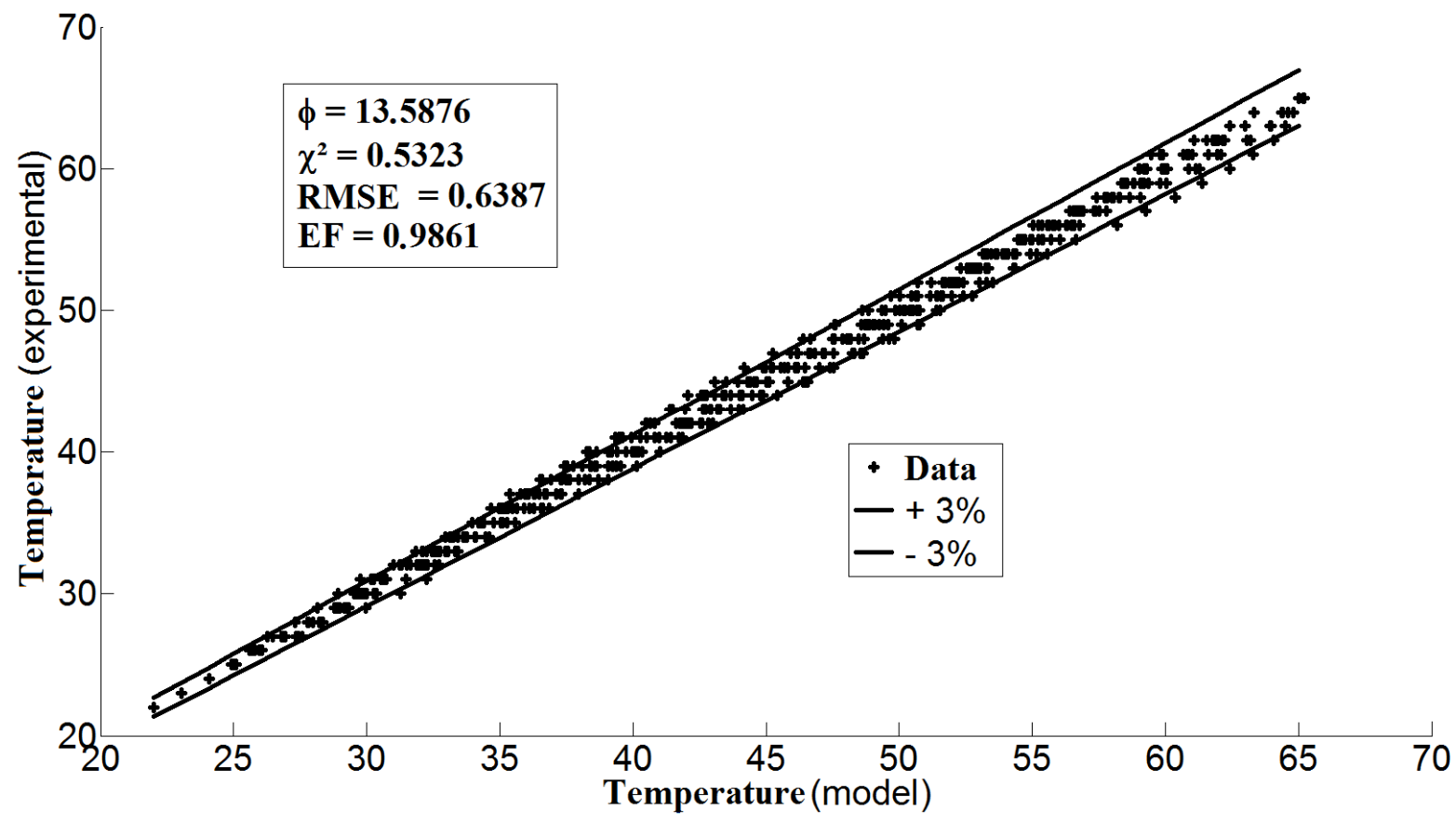

Figure 6 - Global Deviation 


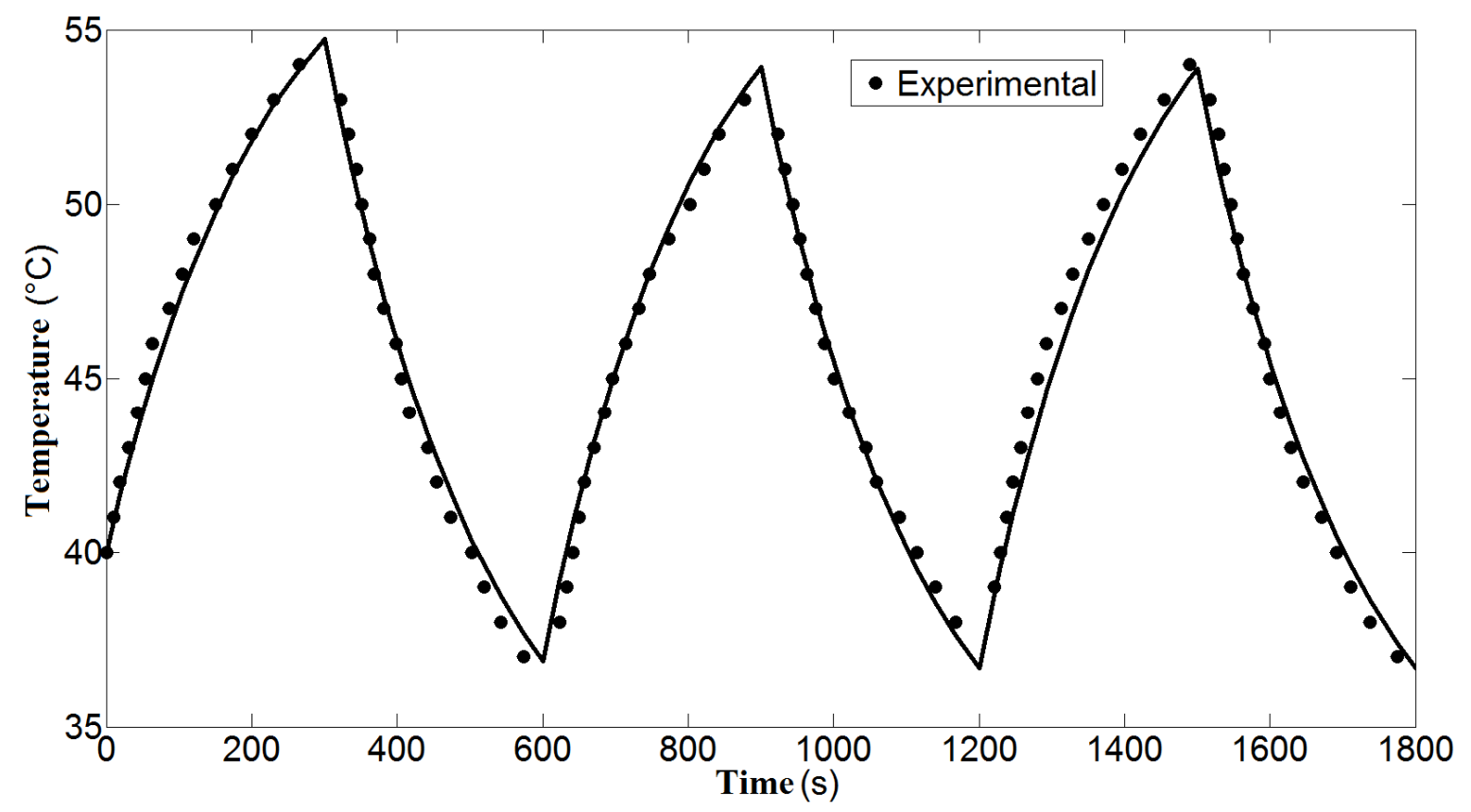

Figure 7 - Experiment with Modulated Temperature

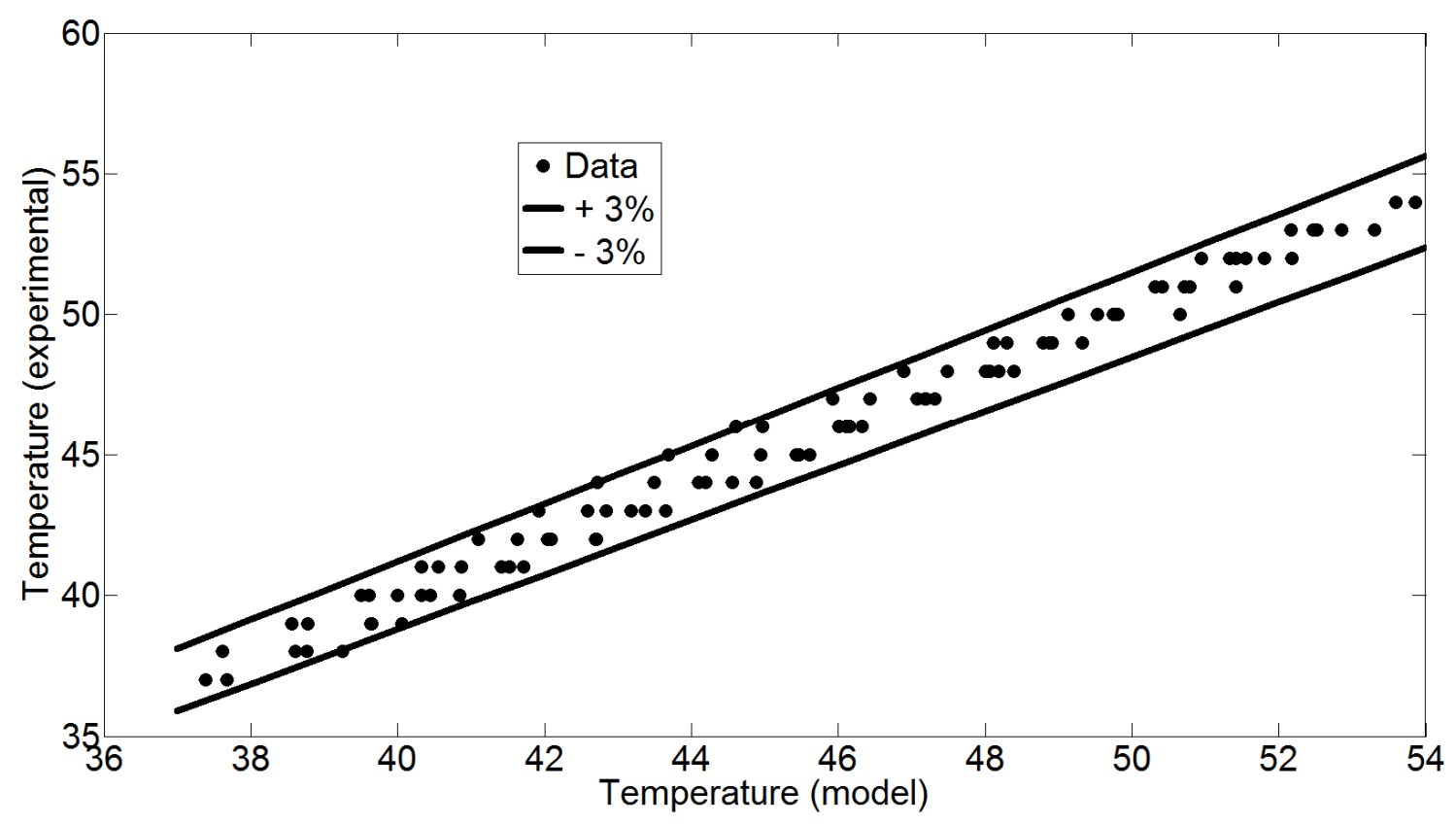

Figure 8 - Global Deviation for Experiment with Modulated Temperature

\section{CONCLUSION}

Results revealed that the model adequately represented the behavior of the system operating in both transient and permanent regimes and showed that this model can be used for simulation, analysis, and design of electric heaters. Moreover, the model was able to predict the behavior of $\mathrm{T}_{\text {out }}$ with a maximum deviation near to $3.0 \%$. The modulated temperature experiment typical for intermittent drying process could also be described by the model with a global deviation near to $3.0 \%$ which is lower than the thermocouple precision. The value obtained for parameter $\mathrm{C}$ was 1.105 $\mathrm{J} / \mathrm{sK}$, resulting in an overall heat transfer coefficient around $10.3 \mathrm{~W} / \mathrm{m}^{2} \mathrm{~K}$, which is within the order of magnitude reported in the literature. 


\section{NOMENCLATURE}

$\begin{array}{lll}A & \text { Parameter of Equation 7 } & (\mathrm{J} / \mathrm{K}) \\ A s & \text { Heater surface area } & \left(\mathrm{m}^{2}\right) \\ B & \text { Parameter of Equation } 7 & (\mathrm{~J} / \mathrm{sK}) \\ C & \text { Parameter of Equation } 7 & (\mathrm{~J} / \mathrm{sK}) \\ c p_{\text {air }} & \text { Specific heat of air } & (\mathrm{J} / \mathrm{kgK}) \\ c p_{\text {box }} & \text { Specific heat of the heater box } & (\mathrm{J} / \mathrm{kgK}) \\ D & \text { Parameter of Equation 12 } & (\mathrm{s}) \\ E & \text { Parameter of Equation 12 } & \left({ }^{\circ} \mathrm{C}\right) \\ h & \text { Overall heat transfer coefficient } & \left(\mathrm{W} / \mathrm{m}^{2} \mathrm{~K}\right) \\ \dot{\mathrm{m}}_{\text {air }} & \text { Air mass flow rate } & (\mathrm{kg} / \mathrm{s}) \\ m_{\text {box }} & \text { Heater box mass } & (\mathrm{kg}) \\ R & \text { Electric resistance } & (\Omega) \\ t & \text { Time } & (\mathrm{s}) \\ T_{\text {amb }} & \text { Ambient temperature } & \left({ }^{\circ} \mathrm{C}\right) \\ T_{\text {in }} & \text { Air temperature at heater inlet } & \left({ }^{\circ} \mathrm{C}\right) \\ T_{\text {out }} & \text { Air temperature at heater outlet } & \left({ }^{\circ} \mathrm{C}\right) \\ V & \text { Voltage } & (\mathrm{V})\end{array}$

\section{REFERENCES}

BIRD, R. B.; STEWART, W. E.; LIGHTFOOT, E. N. Transport Phenomena. John Wiley \& Sons, Inc. Second Edition. 2002, p. 425.

CHUA, K. J.; CHOU, S. K.; HO, J. C.; MUJUMDAR, A. S.; HAWLADER, M. N. A. Cyclic air temperature drying of guava pieces: effects on moisture and ascorbic acid contents. Transactions of the Institution of Chemical Engineers 2000a, 78 (Part C), 72-78.

CHUA, K. J.; MUJUMDAR, A. S.; CHOU, S. K.; HAWLADER, M. N. A.; HO, J. C. Heat pump drying of banana, guava and potato pieces: effect of cyclical variations of air temperature on convective drying kinetics and color change. Drying Technology-An International Journal 2000b, 18 (5), 907936.

CHUA， K.J.; MUJUMDAR, A.S.; CHOU, S.K. Intermittent drying of bioproducts - an overview. Bioresource Technology 2003, 90, 285-295.

CHURCHILL, S. W.; CHU, H. H. S. Correlating equations for laminar and turbulent free convection from a horizontal cylinder. International Journal of Heat and Mass Transfer. v. 18, p. 1049-1053, 1975.

COUTINHO, M. R.; OMOTO, E. S.; OLIVEIRA, U. G.; ANDRADE, C. M. G.; JORGE, L. M. M. Modelagem e Desenvolvimento de um Simulador para Aquecedores Elétricos de Ar. Acta Scientiarum. Technology 2004, 26 (1), 33-37.

HOLOWATY, S. A.; RAMALLO, L. A.; SCHMALKO, M. E. Intermittent drying simulation in deep bed dryer of yerba maté. Journal of Food Engineering 2012, $111,110-114$.

KOWALSKI, S. J.; PAWLOWSKI, A. Intermittent drying of initially saturated porous materials. Chemical Engineering Science 2011, 66, 1893-1905.

KWAK, K.; BAI, C. A study on the performance enhancement of heat pump using electric heater under the frosting condition: Heat pump under frosting condition. Applied Thermal Engineering 2010, 30, 539-543.

LUZ, G. R.; ANDRADE, C. M. G., JORGE, L. M. M.; PARAÍSO, P. R. Análise energética da secagem de farelo 
de soja em secador rotativo indireto. Acta Scientiarum. Technology 2006, 28 (2), 173-180.

MATHUR, S. Safety Considerations in Eletric Gas Heaters. Process Safety Progress 2011, 30 (1), 35-38.

MEISAMI-ASL, E.; RAFIEE, S.; KEYHANI, A.; TABATABAEEFAR, A. Determination of suitable thin layer drying curve model for apple slices (variety-Golab). Plant Omics Journal 2010, 3 (3), 103-108.

MENEGHETTI, V.L.; AOSANI, E.; DA ROCHA, J.C.; DE OLIVEIRA, M.; ELIAS, M.C.; Pohndorf, R.S. Mathematical models for intermittent drying of rice. Revista Brasileira de Engenharia Agrícola e Ambiental 2012, 16 (10), 1115-1120.

OLIVEIRA, C.A.; ROCHA, S.C.S. Intermittent Drying of Beans in a Spouted Bed. Brazilian Journal of Chemical Engineering 2007, 24 (4), 571585.

PERRY, R. H; GREEN, D. W. Chemical engineers' handbook. Editora McGrawHill, 1998. $7^{\text {a }}$ Edição. p. 11-1 a 11-28.

PUTRANTO, A.; XIAO, Z.; CHEN, X.D.; WEBLEY, P.A. Intermittent drying of mango tissues: implementation of the reaction engineering approach. Industrial \& Engineering Chemistry Research 2011, 50, 1089-1098.

RAMALLO, L. A.; LOVERA, N. N.; SCHMALKO, M. E. Effect of the application of intermittent drying on Ilex paraguariensis quality and drying kinetics. Journal of Food Engineering 2010, 97, p. 188-193.

REINATO, C. H. R.; BORÉM, F. M.; VILELA, E. R.; CARVALHO, F. M.; MEIRELES, E. P. Consumo de energia e custo de secagem de café cereja em propriedades agrícolas do sul de Minas Gerais. Revista Brasileira de Engenharia Agrícola e Ambiental 2002, 6 (1), 112116.

SILVA, J. de S; BERBERT, P. A.; AFONSO, A. D. L.; RUFATO, S. Qualidade dos Grãos. In Secagem e
Armazenagem de Produtos Agrícolas. SILVA, J. S. Viçosa: Aprenda Fácil. Viçosa, MG. 2000. p. $63-104$.

YIN, H-J.; Y., Z.; C., A-Q.; Z., A. Experimental research on a novel cold storage defrost method based on air bypass circulation and electric heater. Energy 2012, 37, p. 623-631.

\section{ACKNOWLEDGEMENTS}

This work was supported by the National Council for Scientific and Technological Development - CNPq - Brazil. 